\title{
Distribution update, conservation status and color in life of the rare Amazonian snake, Eutrachelophis papilio Zaher and Prudente 2019 (Serpentes: Xenodontini)
}

\author{
Nathalie CITELI ${ }^{1,2}{ }^{*} \mathbb{0}$, Mariana DE-CARVALHO ${ }^{3,4}$, Reuber BRANDÃO ${ }^{1}$ \\ Universidade de Brasília, Laboratório de Fauna e Unidades de Conservação, Brasília, Distrito Federal, 70910-900, Brazil \\ 2 Universidade de Brasília, Laboratório de Anatomia Comparada dos Vertebrados, Distrito Federal, 70910-900, Brazil \\ 3 Universidade de Brasília, Laboratório de Comportamento Animal, Distrito Federal, 70910-900, Brazil \\ 4 Universidade de Brasília, Laboratório de Solos e Vegetação, Distrito Federal, 70910-900, Brazil \\ * Corresponding author: citeli@outlook.com; (D) https://orcid.org/0000-0003-1587-9380
}

\section{ABSTRACT}

The rare Amazonian snake Eutrachelophis papilio is known from only five individuals, from four localities, belonging to its typeseries, the more recent collected over 10 years ago. Here, we expand its distribution and describe its color in life for the first time. We also provide an estimate of its distribution area using the minimum convex polygon method and identify the values of anthropic pressure within its known distribution range with the Human Footprint Index. The new occurrence is located $291 \mathrm{~km}$ from the nearest known locality and its distribution is associated with pristine forests. Considering its rarity, and the absence of demographic and biological data, we suggest that the species should be classified as Data Deficient by IUCN criteria.

KEYWORDS: conservation status, forest species, human footprint, minimum convex polygon

\section{Distribuição, status de conservação e cor em vida da rara serpente amazônica, Eutrachelophis papilio Zaher and Prudente 2019 (Serpentes: Xenodontini)}

\section{RESUMO}

A rara serpente amazônica Eutrachelophis papilio é conhecida por apenas cinco indivíduos provenientes de quatro localidades e pertencentes à sua série-tipo, sendo o mais recente coletado há mais de 10 anos. No presente trabalho, expandimos sua distribuição e descrevemos sua cor em vida pela primeira vez. Calculamos sua área de distribuição usando o método de mínimo polígono convexo e identificamos os valores de pressão antrópica dentro de sua área de distribuição através do Human Footprint Index. A nova ocorrência está a $291 \mathrm{~km}$ da localidade conhecida mais próxima e toda sua distribuição é associada a florestas bem preservadas. Devido à sua raridade, carências de dados demográficos e biológicos, sugerimos que a espécie seja categorizada como Dados Insuficientes (DD) pelos critérios da UICN.

PALAVRAS-CHAVE: categoria de conservação, espécie florestal, mínimo polígono convexo, pressão antrópica

The snake genus Eutrachelophis was described based on two species from western and middle Amazonia, Eutrachelophis bassleri Myers and McDowell, 2014 and Eutrachelophis steinbachii (Boulenger, 1905), and a third unnamed Amazonian taxon related to E. bassleri. Recently, Zaher and Prudente (2019), based on hemipenis morphology, established the genus Baliodryas to accommodate Eutrachelophis steinbachi, which is restricted to Bolivia and southeastern Brazil. They also redefined Eutrachelophis to accommodate two rare species, E. bassleri (restricted to the Peruvian and Ecuadorian Amazon) and the new Eutrachelophis papilio Zaher and Prudente 2019 (endemic to the Brazilian Amazon), which corresponds to the third taxon discussed by Myers and McDowell (2014).

Eutrachelophis papilio is identified by a single white butterfly-shaped ocellus on the nape, 15/15/15 dorsal scale rows, 139-145 ventral scales, 68-76 subcaudals, eight 
supralabials, nine infralabials, and a hemipenis characterized by long lobes that taper distally (Zaher and Prudente 2019). It is a rare species, known only from the type series, which is composed of five individuals (two juveniles and three adults), the more recent collected over 10 years ago. The species is known to occur in lowland rainforests in southwestern regions of the Brazilian Amazon, having been reported from one municipality in Acre state (Rio Branco) and three in Amazonas state (Careiro da Várzea, Coari, and Lábrea) (Zaher and Prudente 2019).

Here, we report a new occurrence of Eutrachelophis papilio and describe its color pattern in life for the first time. We also estimated its distribution area and discuss its conservation status, considering the presence of anthropogenic impacts and protected areas in its known distribution range.

The description of color is based on a live specimen found during fieldwork, aided with photographs. We describe the color of the body, head, and tail in dorsal, lateral, and ventral view. To estimate the species' distribution range, we calculated the minimum convex polygon (MCP) using Quantum GIS software (QGIS Development Team 2016) using its known locality records. The cumulative human pressure within its estimated distribution area was assessed using the Human Footprint Index (HFPI), based on a quantitative analysis of human influence across the globe (Venter et al. 2016a; 2016b). The HFPI is a globally comprehensive index relevant in assessing the future vulnerability of biodiversity (McGowan 2016). The HFPI map is composed of a combination of human environments, human population density, electric infrastructure, croplands, pasture lands, roads, railways, and navigable waterways at a $1-\mathrm{km}^{2}$ resolution scale (Venter $e t$ al. 2016a; 2016b). In the map, human impact is rated from zero (minimum human footprint) to 50 (maximum human footprint) for each terrestrial biome (Venter et al. 2016b). We used a raster package (Hijmans 2020) in R environment to identify the HFPI values at each pixel $\left(\sim 1 \mathrm{~km}^{2}\right)$ within the MCP. We also inserted the limits of conservation units designed for integral protection of biodiversity and sustainable use (MMA 2019), considering their distinct roles in biodiversity conservation (Françoso et al. 2015), aiming to evaluate the future conservation potential of the area.

During fieldwork, on May 7, 2019, at 2:48 p.m., we found an adult female Eutrachelophis papilio (CHUNB 78616) crossing a trail in the Nascentes do Lago Jari National Park, Tapauá municipality (6 $6^{\circ} 14.00^{\prime \prime} \mathrm{S}, 62^{\circ} 36^{\prime} 51.00^{\prime \prime} \mathrm{W}, 67 \mathrm{~m}$ asl). The individual was in an area close to the BR-319 highway (which connects Porto Velho, Rondônia state, to Manaus, Amazonas state) in the Purus-Madeira interfluve, in the southwestern Brazilian Amazon. The snake was active on the forest floor, moving near tree roots, in a terra firme forest, with large trees and streams nearby, with no signs of human presence. The nearest urban center (Tapauá municipality) was $84 \mathrm{~km}$ away. This new occurrence extends the species' distribution $291 \mathrm{~km}$ southeast of its nearest previously known locality, and is the fifth locality record for the species.

We identified the specimen based on the following characteristics: 15/15/15 dorsal scales, 145 ventrals, 71 subcaudals, eight supralabials (3rd to 5 th touching the orbit), 10 infralabials (five touching the anterior chin shields and two touching the posterior chin shields), temporals $1+2$, nasal divided and cloacal plate divided. The sex was determined by the absence of a hemipenis, verified through a ventral incision at the base of the tail. The individual's morphometric measurements were: total length $=343 \mathrm{~mm}$ (snout-vent length $=251 \mathrm{~mm}$; tail length $=92 \mathrm{~mm}$ ); head length $=10.11 \mathrm{~mm}$; head width $=4.49 \mathrm{~mm}$; eye diameter $=$ $2.45 \mathrm{~mm}$ (corresponding to more than half of its distance from the nostril $=3.04 \mathrm{~mm}$ ); distance between eyes $=3.19$ $\mathrm{mm}$; loreal scale length $=0.72 \mathrm{~mm}$; loreal scale width $=0.55$ $\mathrm{mm}$; frontal scale length $=3.21$; frontal scale width $=1.36$ $\mathrm{mm}$. All dimensions were within the range described for the species (Zaher and Prudente 2019), except for the number of ventral scales, which was higher than that recorded for other females [145 vs 139 (MPEG 18250) and 141 (MPEG 10530), see Zaher and Prudente 2019].

The individual showed white supralabials, with a black upper border. The infralabials and gular were immaculate white. The nuchal ocellus (butterfly-shaped) on the head resembled clear orange circles. There were two dorsolateral rows of 14 dark circular spots ( 1.5 to 2 scales in size) from the neck to the end of the first third of the body. The dorsal surface of the head was dark gray, whereas the anterior portion of the body was grayish, with brownish tones in the middle portion and grayish tones at the posterior end of the body. Lateral sides of the body showed reddish tones spreading onto the external margins of the ventral scales. The belly was white, with external reddish brown borders. The tail was grayish, with a white subcaudal region (Figure 1). The color pattern

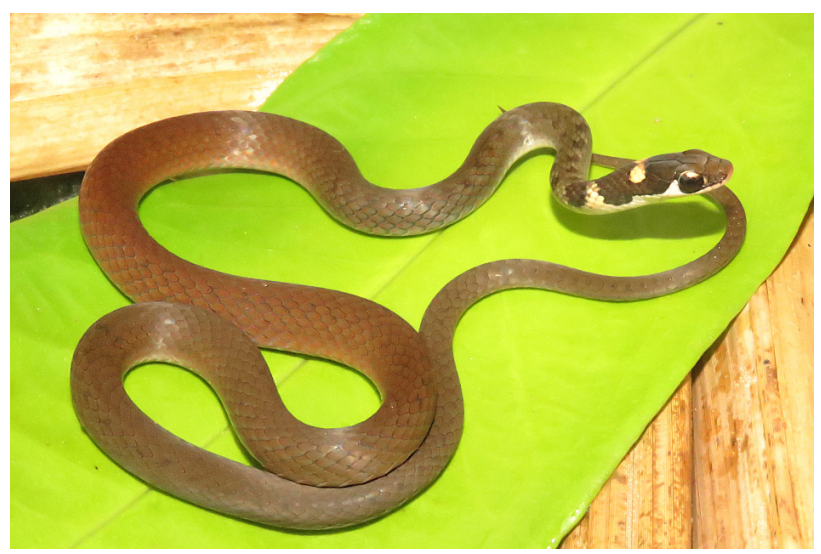

Figure 1. Adult Eutrachelophis papilio female in life, from Nascentes do Lago Jari National Park (CHUNB 78616). Credit: Nathalie Citeli. This figure is in color in the electronic version. 
followed the original description for the species, including the spreading of the dorsal coloration onto the belly (see Zaher and Prudente 2019). However, in our specimen the ocellus (butterfly-shaped) was not white, as in preserved specimens, and we did not detect a lateral line of white dashes or dots along scale row four (see Zaher and Prudente 2019).

The total MCP area corresponded to $169,803 \mathrm{~km}^{2}$, while the HFPI varied from 0 to 27.28 in the circumscribed pixels (Figure 2a). Most of the area within the MCP was very pristine, with a median of 0.003 and mode 0 in HFPI. Despite the low HFPI in most of the MCP, there was a small area $\left(7,431 \mathrm{~km}^{2}\right)$ with high HFPI values ( $\left.\geq 3\right)$, corresponding to large cities and other recently deforested areas. Values $\geq 3$ can correspond to an extinction risk for some species (see DiMarco et al. 2018; O’Bryan et al. 2020). Although most of the distribution range of $E$. papilio covers areas with negligible human impact, the presence of high HFPI areas is indicative of the proximity of the MCP to the influence area of the so-called

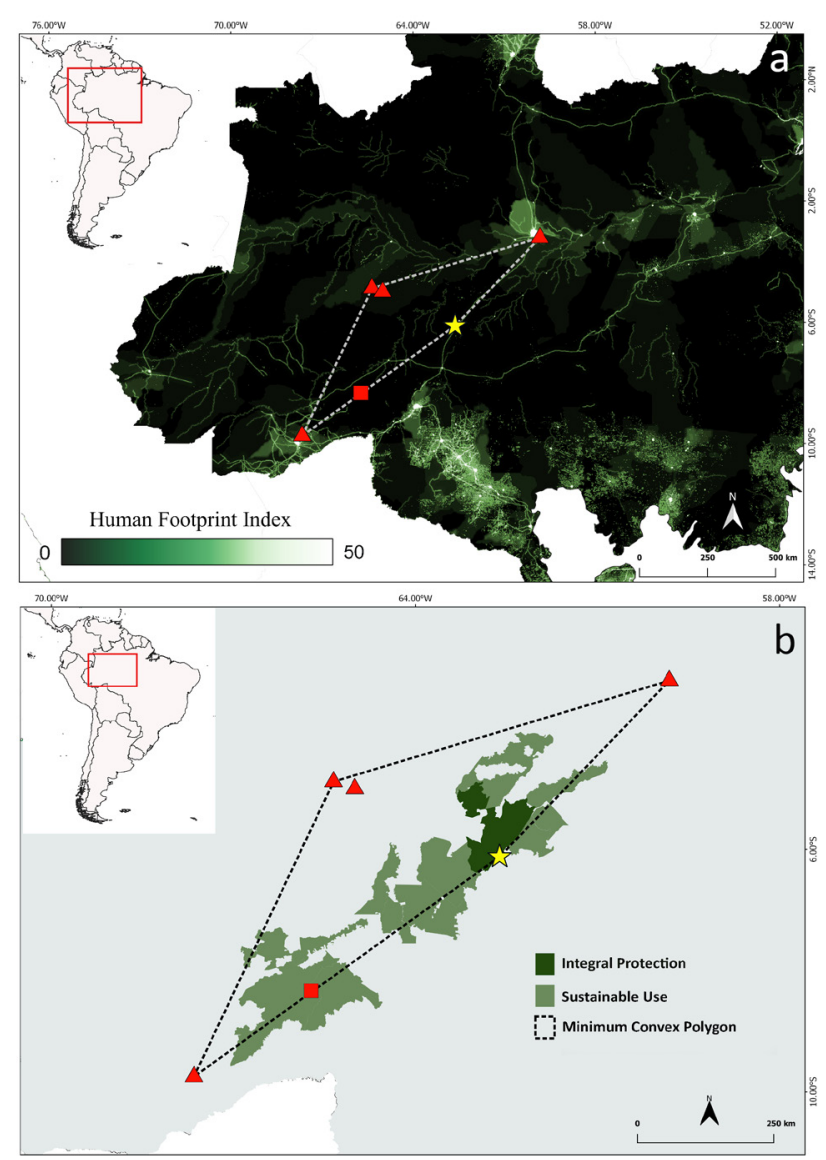

Figure 2. A - Map showing the known distribution range of Eutrachelophis papilio in the southwestern Brazilian Amazon according to the minimum convex polygon method based on the known occurrence localities (red triangles), the type locality (red square), and the new record (yellow star). The color grading shows the level of anthropic impact according to the Human Footprint Index. B - Conservation units within the known distribution range of Eutrachelophis papilio.This figure is in color in the electronic version. deforestation arc, which has the BR-319 highway as a relevant vector of habitat loss in the southwestern Brazilian Amazon (Fearnside and Alencastro-Graça 2006; Barni et al. 2015).

The transition from natural areas to higher HFPI values is associated with the increased risk of species extinction, mainly due to habitat loss (Di-Marco et al. 2018). Areas with the highest HFPI values include the oldest locality records of E. papilio, in the municipalities of Rio Branco (specimen collected in 1990) and Careiro da Várzea (record in 1998) (Zaher and Prudente 2019). Further fieldwork in these localities may determine whether the species still occurs in these areas or if its populations have become locally extinct due to habitat changes caused by the fast advance of human activities in the region (e.g. Ferrante and Fearnside 2018).

There are 13 conservation units in the species' MCP, with the Nascentes do Lago Jari National Park and the Abufari Biological Reserve as the only ones designed for biodiversity protection, with a joint area of $1,046,620$ ha (ICMBio 2020). The other ones, designed for sustainable use of natural resources, are the Ituxi, Médio Purus, Lago Capanã Grande, and Catunama extractivist reserves; the Piagaçu-Purus, Rio Amapá and Igapó-Açú sustainable development reserves; the Iquiri and Balata-Tufari national forests, and the Tapauá and Catunama state forests, adding to a total area of more than 6 million ha (ICMBio 2020; SEMA-AM 2020) (Figure 2b).

The BR-319 highway runs along the central area of the Purus-Madeira interfluve, a large and important center of biodiversity in the Amazon (Ferrão et al. 2017; 2018; Peixoto et al. 2019) that is still little explored (e.g. Simóes 2016; Ortiz et al. 2018). The presence of undescribed (Ferrão et al. 2016), endemic (Simóes 2016), and rare species (present study) highlights the importance of conservation policies for the interfluve, particularly the creation of conservation units for integral protection (Fearnside and Alencastro-Graça 2006). Recent projections for the Purus-Madeira interfluve, with the perspective of pavement of BR-319 highway, are of high deforestation rates and severe habitat loss (Fearnside and Alencastro-Graça 2006; Soares-Filho et al. 2006), likely affecting E. papilio conservation.

Based on the HFPI values found within the MCP, corresponding to large tracts of pristine habitat in its currently known range, E. papilio is possibly related to well-conserved forests. However, despite its presence in a large national park (> $8,000 \mathrm{~km}^{2}$ ), considering the paucity of ecological knowledge about the species, and the high rate of environmental change expected for the Purus-Madeira interfluve in the near future, we suggest that $E$. papilio should be considered a focal species for future studies in the region. We suggest that E. papilio should be classified as Data Deficient by IUCN criteria, considering its recent description, rarity, and scarcity of biological data. 


\section{ACKNOWLEDGMENTS}

We are grateful to A. Guedes, G. Carvalho, and S. Dantas for their assistance in field expeditions; R. F. Macedo, S. Teixeira and anonymous reviewers for useful comments on the manuscript. We are also grateful to Coordenação de Aperfeiçoamento de Pessoal de Nível Superior (CAPES) for financial support, and Instituto Brasileiro do Meio Ambiente e dos Recursos Naturais Renováveis (IBAMA) and Instituto Chico Mendes de Conservação da Biodiversidade (ICMBio) for collecting permits (license \# 02001.00686082005-95 -ABIO 502/2014, and consent SEI \# 59/2018-DIBIO/ ICMBio).

\section{REFERENCES}

Barni, P.E.; Fearnside, P.M.; Alencastro-Graça, P.M.L. 2015. Simulating deforestation and carbon loss in Amazonia: impacts in Brazil's Roraima state from reconstructing Highway BR319 (Manaus-Porto Velho). Environmental Management, 55: 259-278.

Di-Marco, M.; Venter, O.; Possingham, H.P.; Watson, J.E. 2018. Changes in human footprint drive changes in species extinction risk. Nature Communications, 9: 1-9.

Fearnside, P.M.; Alencastro-Graça, P.M.L. 2006. BR-319: Brazil's Manaus-Porto Velho highway and the potential impact of linking the Arc of Deforestation to central Amazonia. Environmental Management, 38: 705-716.

Ferrante, L.; Fearnside P.M. 2018. Amazon sugarcane: a threat to the forest. Science, 359: 1472.

Ferrão, M.; Colatreli, O.; de Fraga, R.; Kaefer, I.L.; Moravec, J.; Lima, A.P. 2016. High species richness of Scinax treefrogs (Hylidae) in a threatened Amazonian landscape revealed by an integrative approach. PloS ONE, 11: e 0165679.

Ferrão M.; Fraga R.D.; Moravec J.; Kaefer I.L.; Lima A.P. 2018. A new species of Amazonian snouted treefrog (Hylidae: Scinax) with the description of a novel species-habitat association for an aquatic breeding frog. PeerJ, 6: e4321.

Ferrão, M.; Moravec, J.; de Fraga, R.; Almeida, A.P.; Kaefer, I.L.; Lima, A.P. 2017. A new species of Scinax from the Purus-Madeira interfluve, Brazilian Amazonia (Anura, Hylidae). ZooKeys, 706: 137-162.

Françoso, R.D.; Brandão, R.; Nogueira, C.C.; Salmona, Y.B.; Machado, R.B.; Colli, G.R.; 2015. Habitat loss and the effectiveness of protected areas in the Cerrado Biodiversity Hotspot. Natureza \& Conservação, 13: 35-40.

Hijmans, R.J. 2020. Raster: Geographic Data Analysis and Modeling. $\mathrm{R}$ package version 3.0-12. (https://CRAN.R-project.org/ package $=$ raster).

ICMBio. 2020. Instituto Chico Mendes de Conservação da Biodiversidade. Unidades de Conservação - Amazônia. (https:// www.icmbio.gov.br/portal/unidadesdeconservacao/biomas- brasileiros/amazonia/unidades-de-conservacao-amazonia/), Accessed on 16 Jun 2020.

McGowan, P.J.K. 2016. Mapping the terrestrial human footprint. Nature, 537: 172-173.

MMA. 2019. Ministério do Meio Ambiente. Áreas Especiais Unidades de Conservação. (http://mapas.mma.gov.br/i3geo/ datadownload.htm). Accessed on 08 Apr 2020.

Myers, C.W.; McDowell, S.B. 2014. New taxa and cryptic species of Neotropical snakes (Xenodontinae), with commentary on hemipenes as generic and specific characters. Bulletin of the American Museum of Natural History, 385: 1-112.

O’Bryan, C.J.; Allan, J.R.; Holden, M.; Sanderson, C.; Venter, O.; Di-Marco, M.; McDonald-Madden, E.; Watson, J.E. 2020. Intense human pressure is widespread across terrestrial vertebrate ranges. Global Ecology and Conservation, 21: e00882.

Ortiz, D.A.; Lima, A.P.; Werneck, F.P. 2018. Environmental transition zone and rivers shape intraspecific population structure and genetic diversity of an Amazonian rainforest tree frog. Evolutionary Ecology, 32: 359-378.

Peixoto, G.M.; Leitão, P.H.; Kaefer, I.L.; Lima, A.P. 2019. The lizards along the road BR-319 in the Purus-Madeira interfluve, Brazilian Amazonia (Squamata, Lacertilia). Herpetology Notes, 12: 689-697.

Quantum GIS Development Team. 2014. QGIS Geographic Information System. Open Source Geospatial Foundation Project. (http://qgis.osgeo.org).

SEMA-AM. 2020. Secretaria do Meio Ambiente do Amazonas. Unidades de Conservação. (http://meioambiente.am.gov.br/). Accessed on 16 Apr 2020.

Soares-Filho, B.S.; Nepstad, D.C.; Curran, L.M.; Cerqueira, G.C.; Garcia, R.A.; Ramos, C.A.; Voll, A.; McDonald, A.; Lefebvre, P.; Schlesinger, P. 2006. Modelling conservation in the Amazon basin. Nature, 440: 520-523.

Simôes, P.I. 2016. A new species of nurse-frog (Aromobatidae, Allobates) from the Madeira River basin with a small geographic range. Zootaxa, 4083: 501-525.

Venter, O.; Sanderson, E.W.; Magrach, A.; Allan, J.R.; Beher, J.; Jones, K.R.; et al. 2016a. Global Human Footprint maps for 1993 and 2009. Scientific Data, 3: 10067.

Venter, O.; Sanderson, E.W.; Magrach, A.; Allan, J.R.; Beher, J.; Jones, K.R.; et al. 2016b. Sixteen years of change in the global terrestrial human footprint and implications for biodiversity conservation. Nature Communications, 7: 12558.

Zaher, H.; Prudente, A.L. 2019. The enigmatic Amazonian genus Eutrachelophis: morphological evidence and description of new taxa (Serpentes: Dipsadidae: Xenodontini). Amphibia-Reptilia, 1: $1-17$.

\section{RECEIVED: $25 / 04 / 2020$}

ACCEPTED: 08/07/2020

ASSOCIATE EDITOR: Paulo E. Bobrowiec 